\title{
Anaerobic respiration in the unsaturated zone of agricultural soil mobilises phosphorus and
}

\section{manganese}

Ruben Warrinnier $*_{\dagger} \dagger$, Sara Bossuyt $\uparrow$, Camille Resseguier $\ddagger$, Philippe Cambier $\ddagger$, Sabine Houot Jon Petter Gustafssonłt, Jan Diels $\dagger$, and Erik Smolders $\dagger$

$\dagger$ Division of Soil and Water Management, KU Leuven, Kasteelpark Arenberg, 20, B-3001

Leuven, Belgium

\$INRA, UMR 1402 ECOSYS, F-78850 Thiverval-Grignon, France ECOSYS, INRA, AgroParisTech, Université Paris-Saclay, 78850 Thiverval-Grignon, France

†t Department of Soil and Environment, Swedish University of Agricultural Sciences (SLU), Box 7014, 75007 Uppsala, Sweden 
2 Anaerobic conditions mobilise phosphorus (P) in soils and sediments. The role of anaerobic

3 microsites in well-drained soil on $\mathrm{P}$ migration is unknown. This study aimed to identify

4 mechanisms that control field-scale vertical P mobility as affected by organic fertilisers that may

5 trigger variable redox conditions. Soils were sampled at different depths in a well-drained Luvisol

6 after 19-years of application of organic fertilisers. The concentrations of P and manganese (Mn)

7 in $0.45-\mu \mathrm{m}$-filtered extracts $\left(10^{-3} \mathrm{M} \mathrm{CaCl}_{2}\right)$ of field-moist soil samples were strongly correlated $(\mathrm{r}$

$8=+0.95)$ and both peaked in and below the compacted plough pan; suggesting that reductive

9 processes mobilise P. Waterlogged soil incubations confirmed that anaerobic respiration co-

10 mobilises $\mathrm{Mn}$ and $\mathrm{P}$ and that this leads to the release of colloidal $\mathrm{P}$ and iron (Fe). The long-term

11 applications of farmyard manure and immature compost enhanced the concentrations of $\mathrm{Mn}, \mathrm{Fe}$,

12 and aluminium (Al) in the soil solution of subsurface samples, whereas less such effect was found

13 under the application of more stable organic fertilisers. Farmyard manure application significantly

14 enhanced soil P stocks below the plough layer despite a small P input. Overall, multiple lines of

15 evidence confirm that anaerobic respiration, sparked by labile organic matter, mobilises $\mathrm{P}$ in this

16 seemingly well-drained soil. 
17 TOC ART

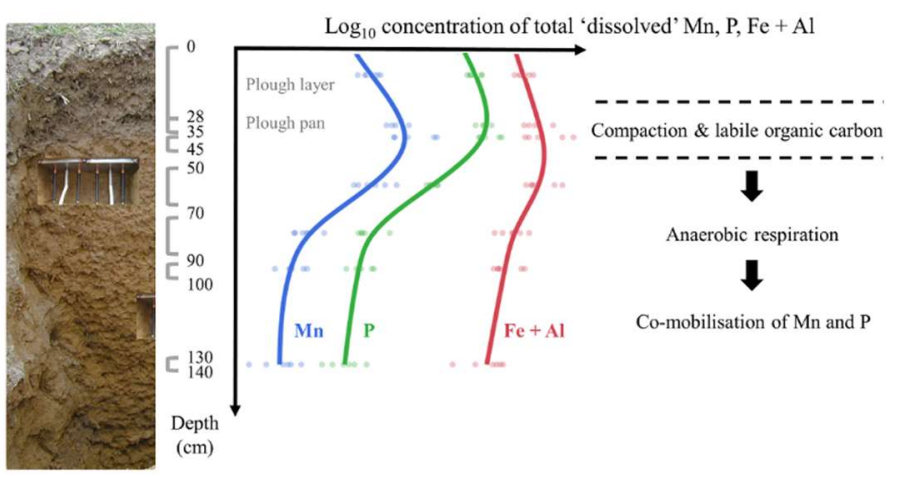


21 The legacy excess phosphorus $(\mathrm{P})$ in agricultural soil is a chronic threat for surface water quality. ${ }^{1}$

22 Vertical leaching is considered slow and less critical than erosion. ${ }^{1}$ The slow migration in soil is

23 due to the large retardation of the orthophosphate anion $\left(\mathrm{PO}_{4}\right)$ by sorption on iron $(\mathrm{Fe})$ and

24 aluminium (Al) oxyhydroxides and/or precipitation with calcium $(\mathrm{Ca})$ as Ca-phosphates at high

$25 \mathrm{pH}$ values. ${ }^{2}$ The theoretical $\mathrm{PO}_{4}$ retardation factor in an agricultural soil of the temperate climate

26 is about 2000 (i.e. the time to travel a certain distance relative to that of a non-sorbing compound),

27 which leads to theoretical half-lives of $\mathrm{P}$ in topsoil of more than 500 years at a typical annual

28 drainage in temperate regions of $200 \mathrm{~mm}$ year $^{-1}{ }^{3,4}$ However, several field observations do not

29 confirm that theoretical retardation and show marked P migration. For example, two surveys, of

30 Danish and Flemish soil cores, confirmed strong subsurface accumulation of $\mathrm{P}$, down to $60-90 \mathrm{~cm}$

31 depth. ${ }^{5,6}$

32 The $\mathrm{PO}_{4}$ mobility can be accelerated in a soil profile by various processes such as colloid-mediated

33 transport and redox-related release of $\mathrm{PO}_{4}$. Different column and field studies have confirmed that

34 mobile colloids, i.e. particles with a diameter $<1 \mu \mathrm{m}$, bind $\mathrm{PO}_{4}$ and facilitate $\mathrm{P}$ transport, up to a

35 factor of 50..$^{3,7-11}$ The factors controlling colloid-fluxes are, however, not well known. Increasing

$36 \mathrm{Ca}^{2+}$ concentrations decrease organic-matter-(OM)-stabilized Fe and $\mathrm{Al}$ oxyhydroxide colloid

37 concentrations in freshwater by enhancing flocculation. ${ }^{12,13}$ This trend is also observed in soil

38 leachates, $\mathrm{Fe}$ and $\mathrm{Al}$ colloid concentrations sharply rise when solution $\mathrm{Ca}^{2+}$ drops below $1 \mathrm{mM}^{3}$

39 In addition, decreasing $\mathrm{pH}$ in streams is associated with increasing concentration of Fe-rich

40 colloids, likely because acid waters are associated with high dissolved organic carbon (DOC)

41 concentrations and organic anion sorption stabilizes Fe colloids. ${ }^{12,14}$ 
42 Reducing conditions dissolve $\mathrm{Fe}$ oxyhydroxides and release sorbed $\mathrm{PO}_{4}$, thereby dissolved $\mathrm{PO}_{4}$

43 concentrations can increase by several orders of magnitude. ${ }^{15,16}$ This process is well demonstrated

44 in soils submerged for rice culture. ${ }^{17}$ Interestingly, Henderson et al. showed that waterlogging

45 soils, incubated in laboratory conditions with the addition of a carbon (C) source, released P-

46 bearing colloids into solution. ${ }^{18}$ Ferric Fe, Fe(III), was suggested to act as cement in soil aggregates

47 and its dissolution releases mineral P-bearing colloids. Similarly, drying/rewetting and anoxic/oxic

48 cycles are often found to release P and colloids. ${ }^{19,20}$ It is unclear if that is related to biological

49 processes, such as microbial cell lysis or organic matter disruption, or due to reductive $\mathrm{P}$ release. ${ }^{21}$

50 Manganese $(\mathrm{Mn})$ is an even more redox-sensitive element than Fe, exists in three oxidation states

51 (+II, + III and +IV) in the environment, and its reductive dissolution precedes that of Fe upon

52 waterlogging. ${ }^{22}$ Manganese (+II) is present as a dissolved cation, $\mathrm{Mn}(+\mathrm{III})$ can be both dissolved

53 or form particulate oxyhydroxides and Mn(IV) is present as particulate Mn oxyhydroxides. ${ }^{23}$ Rapid

54 Mn redox cycling can control respiration at oxic-anoxic interfaces and in forest floors. ${ }^{24,25} \mathrm{In}$ soil,

55 Mn oxyhydroxides form strong associations with Fe oxyhydroxides, especially in redoximorphic

56 soils. ${ }^{26,27}$ Pure Mn oxyhydroxides have a $\mathrm{pH}$-dependent charge with a point-of-zero-charge

57 ranging from 1.5 to 4.6 ; resulting in a negative charge at near-neutral $\mathrm{pH}$ values. ${ }^{26}$

58 The role of redox cycling on P migration is generally studied in wetlands, not in well-drained

59 agricultural soils. ${ }^{21}$ However, well-drained soils can have anoxic microsites, ${ }^{28}$ in which OM

60 decomposition slows down, ${ }^{28}$ denitrification takes place ${ }^{29}$ and nitrous oxide $\left(\mathrm{N}_{2} \mathrm{O}\right)$ and methane

$61\left(\mathrm{CH}_{4}\right)$ are produced. ${ }^{30}$ Potentially, such microsites may be hot spots for release of $\mathrm{P}$ and, as far as

62 known, this process is yet unverified at field-scale. Anoxic microsites form in soil aggregates when

63 oxygen gas $\left(\mathrm{O}_{2}\right)$ diffusion into the aggregate is insufficient to compensate for $\mathrm{O}_{2}$ consumption by

64 micro-organisms. ${ }^{31}$ Large water-filled pore space (WFP) of the aggregates, large content of labile 
65 soil $\mathrm{OM}$ and high temperature (T) enhance the anoxic microsite formation. ${ }^{29,31}$ Traditionally, $\mathrm{N}_{2} \mathrm{O}$

66 fluxes have been related to soil physical parameters (large bulk density, $\mathrm{T}$ and clay content) and

67 architecture. ${ }^{29}$ For example, soil compaction and zero-tillage were found to trigger $\mathrm{N}_{2} \mathrm{O}$ fluxes as

68 compared to tilled and well-structured soil, especially in warm and wet conditions. ${ }^{29}$ More

69 recently, a planar optode imaging system showed that microsites (i.e. spaces with less than $5 \%$

70 oxygen saturation) constituted $14-85 \%$ of the total pore volume, while bulk oxygen concentrations

71 were $40-100 \%$ of saturation. ${ }^{32}$ This anoxic volume increased with increasing soil clay content. ${ }^{32}$

72 In a Retisol, reductive Fe(III) and Mn(IV) dissolution were observed. ${ }^{11}$ Reduction of Fe(III)

73 minerals in riparian soils can increase P mobility by an order of magnitude ${ }^{16}$ and we expect that

74 this can occur within anoxic microsites of well-drained soils.

75 The objective of this study was to unravel the mechanisms controlling P mobility at field scale and

76 the effect of OM management on these. The Qualiagro long-term field trial, in Feucherolles

77 (France), offers a unique opportunity for this because of the long-term treatments with different

78 organic amendments and because wick samplers are installed that monitor in situ leaching from

792013 until present. ${ }^{33}$ Soils from this trial had been sampled before for measuring P leaching in

80 disturbed columns. ${ }^{3}$ That study showed that the leachate $\mathrm{P}$ concentrations were in general

81 determined by $\mathrm{PO}_{4}$ sorption on bulk soil $\mathrm{Fe}$ and $\mathrm{Al}$ oxyhydroxides and that colloidal forms of these

82 oxyhydroxides accelerated $\mathrm{P}$ transport. ${ }^{3}$ The controlling factors at field scale remain poorly

83 resolved. Therefore, the strategy here was to analyse element associations and seasonality in long-

84 term wick leachates, to analyse $\mathrm{P}$ solubility (through $\mathrm{CaCl}_{2}$ extracts with fresh soil) and speciation

85 (through P K-edge X-ray absorption near edge structure (XANES) spectroscopy) at various depths

86 under various treatments. Finally, to underpin the causality behind the observations, P release and

87 fractionation ("colloidal" versus "truly dissolved") was experimentally analysed in a waterlogged 
88 soil incubation and dialysis experiment. Throughout this work, size classes of the elements are

89 operationally defined. Elements that do pass the $0.45-\mu \mathrm{m}$-pore-size-filters but not the dialysis

90 membranes (with a molecular weight cut-off of 10-12 kDa or about $3 \mathrm{~nm}^{34}$ ) are called "colloids".

91 "Truly dissolved" elements are those entities that pass the dialysis membranes and are thus smaller

92 than ca. $3 \mathrm{~nm} .{ }^{34}$ Filterable $(0.45 \mu \mathrm{m})$ elements are referred to as "total 'dissolved"' and thus include

93 both "colloidal" as "truly dissolved" entities. 


\subsection{Observational part: soil core characterisation, $\mathrm{CaCl}_{2}$ extracts and wick leachate data}

In a long-term field experiment, observations on the solubility of phosphorus $(\mathrm{P})$ in soil were made

97 by analysis of leachate that was collected by wick samplers and by analysis of $0.45-\mu \mathrm{m}$-filtered

98 calcium chloride $\left(\mathrm{CaCl}_{2}\right)$ extracts of field-moist soil samples of various depths and treatments $(105$

99 samples). On all samples, the content of poorly crystalline Fe, Al and Mn oxyhydroxides, the

100 organic carbon content and the nitrogen content were determined. The solid phase $\mathrm{P}$ speciation

101 was investigated by P K-edge XANES spectroscopy on a subset of samples.

\subsubsection{Field experiment and wick sampler data}

103 The experiment started in 1998 in Feucherolles (Yvelines, France) on a silt loam Glossic Luvisol,

104 a typical arable soil for the Paris Basin (description of soil horizons is given in Figure S1 of the

105 supporting information, SI). The experiment evaluates the agronomic value and environmental

106 impact of different organic amendments. Apart from the mineral $\mathrm{N}$ treatment (MIN N), four

107 different organic fertiliser have been applied every two years on an equal carbon (C) basis: an

108 immature municipal solid waste compost (MSW), dairy farmyard manure (FYM) and two more

109 stable, less biodegradable composts, one is a mixture of green waste and the source-separated

110 organic fraction of municipal waste, $\mathrm{BIO}$, and another is compost of green waste, wood chips and

111 sewage sludge, GWS. ${ }^{35}$ Four glass fibre wick samplers are installed in one field plot per treatment,

112 two at 45 and two $100 \mathrm{~cm}$ depth, to collect percolating water (Figure S1). ${ }^{33}$ From the autumn of

1132012 until summer 2018, leachates were pumped out about twice a month, depending on the

114 precipitation and analysed for $\mathrm{pH}$, dissolved organic carbon, DOC; inorganic carbon, IC; nitrate,

$115 \mathrm{NO}_{3}^{-}$; sulphate, $\mathrm{SO}_{4}^{2}$; chloride, $\mathrm{Cl}^{-}$; P; silicon, $\mathrm{Si}$ and the major cations; the full list is in Table $\mathrm{S} 1$. 
116 Temperature and volumetric moisture content $\left(\theta_{\mathrm{v}}\right)$ were measured at various depths. More details

117 have been published previously ${ }^{33,36}$ and are provided in SI, section S1.

\subsubsection{Soil core sampling and analyses}

119 On the $1^{\text {st }}$ of March 2018, 15 soil cores (three for each plot) were sampled next to the location of 120 the wick samplers, down to a depth of $140 \mathrm{~cm}$. The outside temperature was $-2{ }^{\circ} \mathrm{C}$. Each of the 121 soil cores is considered as an independent sampling replicate of a treatment. Sampling was done

122 using a motorized sampler with a hydraulic impact system (Geonor, Norway; $2 \mathrm{~cm}$ core diameter).

123 These soil cores were divided into seven layers: $0-28 \mathrm{~cm}$ (plough layer with an average bulk 124 density, $\rho_{\mathrm{b}}$, of $\left.1320 \mathrm{~kg} \mathrm{~m}^{-3}\right)^{37} ; 28-35 \mathrm{~cm}$ (compacted plough pan; $\left.\rho_{\mathrm{b}}=1490 \mathrm{~kg} \mathrm{~m}^{-3}\right)^{37} ; 35-45 \mathrm{~cm}$; $12550-70 \mathrm{~cm} ; 70-90 \mathrm{~cm} ; 90-100 \mathrm{~cm}$ and $130-140 \mathrm{~cm}$ depth. Each layer was transferred to a closed 126 plastic bag, stored in a cooling box, before being stored at $4^{\circ} \mathrm{C}$. The upper soil layer was frozen at 127 the time of sampling while subsurface soil temperature increased with depth: from $2{ }^{\circ} \mathrm{C}$ at $40 \mathrm{~cm}$ 128 depth to $7{ }^{\circ} \mathrm{C}$ at $160 \mathrm{~cm}$ (data from $26^{\text {th }}$ of February). The gravimetric moisture content $\left(\theta_{\mathrm{g}}\right)$ and 129 the calcium chloride $\left(\mathrm{CaCl}_{2}\right)$ extractions were performed within two weeks after sampling.

130 Calcium chloride extractions $\left(1 \mathrm{mM} \mathrm{CaCl}_{2}\right.$, solid-liquid ratio $=0.25 \mathrm{~kg} \mathrm{~L}^{-1} ; 24$ hours $)$ were 131 performed on duplicate subsamples of each fresh soil sample, but duplicate analytical data were 132 averaged because the statistical tests on treatments only used the mean data of each of three 133 independent sampling replicates. Ten gram of field moist soil was added to a polyethene tube 134 (volume $=50 \mathrm{ml}$ ) and $1 \mathrm{mM} \mathrm{CaCl}_{2}$ solution was added until the tubes were completely filled (i.e. 135 no headspace). These were shaken in an end-over-end shaker $\left(0.42 \mathrm{~s}^{-1} ; \mathrm{T}=20+/-2{ }^{\circ} \mathrm{C}\right)$ for 24 136 hours, centrifuged at $2500 \mathrm{~g}$ for ten minutes, filtered over $0.45 \mu \mathrm{m}$ (Chromafil ${ }^{\circledR}$ Xtra PET-45/25;

137 Macherey-Nagel, Germany), thereby discarding the first droplets, and acidified using concentrated 
138 nitric acid (65\% $\mathrm{HNO}_{3}$; ultra-pure; Chem-Lab NV, Belgium) to a volume percentage of $1 \%$; prior

139 to analysis of the concentrations of $\mathrm{P}, \mathrm{Fe}, \mathrm{Al}, \mathrm{Mn}$ and $\mathrm{Ca}$ by ICP-MS and ferrous Fe, Fe(II), by the

140 ferrozine method. ${ }^{38}$ The Limit of Quantification (LOQ) for P was $0.15 \mu \mathrm{M}$ and for Fe(II) $0.52 \mu \mathrm{M}$.

141 The $\mathrm{pH}$ was measured in the supernatants after centrifugation. A test was performed assessing

142 potential artificial oxidation of soil samples during handling and extraction (section S2). That test

143 showed that the 24-hours $\mathrm{CaCl}_{2}$ extraction of fresh soil in ambient conditions yielded less total

144 'dissolved' $\mathrm{P}$ and Fe $(<0.45 \mu \mathrm{m})$ than a comparable extraction inside an anoxic glove box and

145 thus confirms that some oxidation reactions occur at ambient conditions. Hence, our findings based

146 on extractions under ambient conditions underestimate the reduced state of the in situ soil.

147 Moreover, several lines of evidence are also given in section S2 that it does not overestimate that

148 reduced state.

149 Oxalate extractions were performed on air-dried, $2 \mathrm{~mm}$ sieved and ground soil samples to

150 determine the concentration of poorly crystalline Fe, Al and Mn oxyhydroxides and associated P. ${ }^{39}$

151 The concentrations in that extract were measured by ICP-OES (Inductively Coupled Plasma-

152 Optical Emission Spectroscopy; Thermo Scientific, ICAP 7000 series). Organic carbon (OC) and

153 total nitrogen $(\mathrm{N})$ content were determined in oven-dried $\left(70{ }^{\circ} \mathrm{C}\right)$ subsamples by an elemental

154 analyser (EA1108 Carlo Erba, Val de Reuil, France). The P speciation was investigated by use of

155 P K-edge XANES spectroscopy, which was carried out at BL-8 at the Synchrotron Light Research

156 Institute (SLRI), Nakhon Ratchasima, Thailand (details in section S3).

157 2.2 Experimental part: waterlogged soil incubations and anoxic dialysis experiment

158 Waterlogged soil incubations were performed to analyse the possible causality behind the 159 association of $\mathrm{P}$ and Mn mobility in the field data. Air-dried soil was incubated for one month 
160 under waterlogged conditions and respiration was monitored along with mobilisation of elements,

161 thereby fractionating the solution by sequential filtration $(0.45 \mu \mathrm{m})$ and dialysis $(<10-12 \mathrm{kDa})$.

162 This allowed calculation of operationally defined size classes: "colloidal" $(<0.45 \mu \mathrm{m} ;>10-12$

$163 \mathrm{kDa}$ or ca. $\left.3 \mathrm{~nm}^{34}\right)$ and "truly dissolved" $(<10-12 \mathrm{kDa})$ entities of elements.

164 Additionally to the soil that was sampled on $01 / 03 / 2018$ (section 2.1.2), extra soil was sampled in 165 the plots amended with farmyard manure (FYM), bio-compost (BIO) and mineral $\mathrm{N}$ fertilisers 166 (MIN N). On two lines at 1.0 and $1.5 \mathrm{~m}$ distance from the wick samplers, ten cores were sampled 167 (20 in total). Only the soil from the $28-45$ and $103-120 \mathrm{~cm}$ was retained and all cores per plot were 168 homogenised to yield six samples in total (two depths for the three treatments) and air-dried. 169 Subsamples from these were incubated (in duplicate), while saturated with water, for up to one 170 month, yielding 12 incubations in total.

171 Air-tight glass vials $(300 \mathrm{ml})$ were filled with $50 \mathrm{~g}$ air-dried, $2 \mathrm{~mm}$ sieved and crushed soil. To 172 this, $250 \mathrm{ml} 1 \mathrm{mM} \mathrm{CaCl}_{2}$ solution was added, yielding a total volume that was slightly below 300 $173 \mathrm{ml}$ and an insignificant headspace. The selected $\mathrm{Ca}^{2+}$ concentration of $1 \mathrm{mM}$ was considered 174 relevant for in situ conditions, wick leachate Ca concentrations ranged 1-4 $\mathrm{mM}\left(\mathrm{P}_{10}-\mathrm{P}_{90}\right.$, see Table $175 \mathrm{~S} 1$ ), higher concentrations could decrease colloidal $\mathrm{Fe}$ and $\mathrm{Al}$ as $\mathrm{Ca}^{2+}$ is a prime colloidal 176 flocculating cation in these conditions. The suspensions were placed on an end-over-end shaker $177\left(0.42 \mathrm{~s}^{-1}\right)$ in darkness at $20 \pm 1{ }^{\circ} \mathrm{C}$. At seven moments in time (between one day and one month), 178 the vials were opened inside a glove box with $\mathrm{N}_{2} / \mathrm{H}_{2}(95 / 5)$ atmosphere and with platinum 179 catalysers converting any trace $\mathrm{O}_{2}$ to $\mathrm{H}_{2} \mathrm{O}$ (Coy Laboratory Products, Grass Lake, United States) 180 and $18 \mathrm{ml}$ suspension was sampled with a syringe and $0.45-\mu \mathrm{m}$-filtered. A $5 \mathrm{~mL}$ subsample was 181 dialysed (see below), another subsample was acidified pending ICP-MS analysis, another was used 182 to determine inorganic carbon (IC) in a TOC analyser (Shimadzu, TOC-L), and a final one to 
183 determine nitrate via the hydrazanium sulfate reduction method in a continuous flow analyser 184 (Skalar). After sampling, the $\mathrm{pH}$ of the suspension was measured and $18 \mathrm{ml}$ of deoxygenated 1 $185 \mathrm{mM} \mathrm{CaCl}_{2}$ was added to maintain a constant volume throughout the experiment. The release of 186 elements was corrected for the removal by sampling (section S4, equation 1). Respiration was 187 calculated from the cumulative release of IC, also corrected for removal by periodic sampling. The 188 inorganic $\mathrm{C}$ is ca. $95 \%$ in the liquid phase and not in a conservative high estimated headspace 189 volume of $10 \mathrm{~mL} \mathrm{vial}^{-1}$. The dialysis of the $5 \mathrm{ml}$ filtered suspension was performed in the glovebox 190 with dialysis bags (molecular weight cut off $=10-12 \mathrm{kDa}$; Spectra/Por ${ }^{\circledR} 4$ Dialysis Membrane 191 Standard RC Tubing; Spectrum Laboratories, Inc. Rancho Dominquez, United States) against 45 $192 \mathrm{~mL}$ deoxygenated $1 \mathrm{mM} \mathrm{CaCl} 2$ solution for $24 \mathrm{~h}$ on a benchtop end-over-end shaker $\left(0.19 \mathrm{~s}^{-1}\right)$. 193 Preliminary experiments showed that equilibrium was reached within $24 \mathrm{~h}$. The outer solution 194 (dialysate) was sampled, acidified and analysed using ICP-MS to obtain the concentrations of truly 195 dissolved elements. 


\subsection{Subsoil enrichment with $P$ and speciation as analysed by $P$ K-edge XANES}

198 Nineteen years of excess P input via organic matter application has enriched the subsoil (depth $>$

$19928 \mathrm{~cm}$ ) with $\mathrm{P}$ (Table $\mathrm{S} 4)$. Table 1 provides the net $\mathrm{P}$ balances ( $\mathrm{P}$ input through fertilisation minus

200 P export via grains and residues). The composted sludge application (GWS) yielded the highest

201 net $\mathrm{P}$ balance $\left(85.0 \mathrm{~kg} \mathrm{P} \mathrm{ha}^{-1}\right.$ year $\left.^{-1}\right)$ because the annual $\mathrm{P}$ application $\left(113 \mathrm{~kg} \mathrm{P} \mathrm{ha} \mathrm{k}^{-1}\right)$ was almost

202 fivefold the annual export $\left(28 \mathrm{~kg} \mathrm{P} \mathrm{ha}^{-1}\right)$. Both the municipal solid waste compost (MSW) and the

203 mineral $\mathrm{N}$ treatment (MIN N) yielded a negative $\mathrm{P}$ balance, due to their low $\mathrm{P}$ content. A significant

204 subsoil enrichment of the oxalate extractable $\mathrm{P}\left(\mathrm{P}_{\mathrm{Ox}}\right)$ and the degree of phosphate saturation (DPS,

205 i.e. $\mathrm{P}_{\mathrm{Ox}} / 0.5\left(\mathrm{Fe}_{\mathrm{Ox}}+\mathrm{Al}_{\mathrm{Ox}}\right)$ ), relative to $\mathrm{MIN} \mathrm{N}$, was found for GWS down to $50-70 \mathrm{~cm}$, down to 28 -

$20635 \mathrm{~cm}$ for the farmyard manure application (FYM; p-value is 0.07 for enrichment in $35-45 \mathrm{~cm}$

207 layer, Table S4) and down to $28-35 \mathrm{~cm}$ for the bio-compost application (BIO; Table S4).

208 Qualiagro's topsoil $(0-28 \mathrm{~cm})$ contains about $20 \mathrm{mmol} \mathrm{kg}^{-1}$ poorly crystalline $\mathrm{Al}\left(\mathrm{Al} \mathrm{Ox}_{\mathrm{Ox}}\right) ; 50 \mathrm{mmol}$

$209 \mathrm{~kg}^{-1}$ poorly crystalline $\mathrm{Fe}\left(\mathrm{Fe}_{\mathrm{O}}\right)$ and $7 \mathrm{mmol} \mathrm{\textrm {kg } ^ { - 1 }}$ poorly crystalline $\mathrm{Mn}(\mathrm{Mn} O \mathrm{Ox})$; apart from the

210 GWS topsoil that contains $29 \mathrm{mmol} \mathrm{Al} \mathrm{kg}{ }^{-1}$ and $60 \mathrm{mmol} \mathrm{Fe} \mathrm{kg}^{-1}$ (Table S4). On average, $9 \%$ of

211 the oxalate extractable oxyhydroxide fraction in the topsoil consists of $\mathrm{Mn}$ and this fraction does

212 not change with depth in the deeper soil layers (Table S4). The organic carbon (OC) and nitrogen

213 (N) content decrease significantly with depth for all treatments (i.e. the slope of a linear relation is

214 sign. negative $\mathrm{p}<0.0001)$.

215 A summary of the P K-edge XANES results is shown in Table S4. Linear combination fitting was

216 used to differentiate between $\mathrm{P}$ adsorbed on Al oxyhydroxides, P adsorbed on Fe oxyhydroxides, 217 iron phosphate precipitates $\left(\mathrm{FePO}_{4}\right.$; not detected in any sample), aluminium phosphate precipitates 
$218\left(\mathrm{AlPO}_{4}\right.$; detected in one sample), calcium phosphates (Ca-P) and organic phosphorus. In all 219 samples, at least $60 \%$ (and up to $70 \%$ ) of the $\mathrm{P}$ is adsorbed on $\mathrm{Fe}$ and $\mathrm{Al}$ oxyhydroxides. This is

220 in line with the previously reported finding that leachate $\mathrm{P}$ concentrations from columns with these

221 soils were controlled by the sorption of orthophosphate on Fe and Al oxyhydroxides. ${ }^{3}$ Calcium

222 phosphates were present in all samples, varying between 16 and $36 \%$ of the $\mathrm{P}$, but these are

223 generally considered not-readily exchangeable. ${ }^{40}$ Organic $\mathrm{P}$ was present as a minor fraction, 224 generally around $10 \%$, which is consistent with the relatively low organic $\mathrm{C}$ content $\left(\sim 10 \mathrm{~g} \mathrm{C} \mathrm{kg}^{-}\right.$ $225^{1}$ ) of these soils.

\subsection{Observations suggest that anaerobic respiration mobilises colloids and $P$ in the field}

227 A weight of evidence suggests that anaerobic conditions occur in this seemingly well-drained soil 228 and that these conditions mobilise colloids and $\mathrm{P}$, as has been reported previously in wetlands and 229 controlled laboratory redox experiments. ${ }^{18,20,41}$ This evidence is supported by the soil horizon 230 description, trends and element associations in wick leachates and soil extracts and the 231 combination of elemental composition in soil extracts in relation to soil properties, water-filled 232 pore space, soil depth and treatments.

233 Mottling in the $\mathrm{B}_{\mathrm{tgd}}$ horizon (Figure $\mathrm{S} 1$ ) provides a first clue for redox processes taking place and 234 may be explained by temporal stagnant water since the clay content of the $50-90 \mathrm{~cm}$ layer is highest 235 in this zone (30\% vs. $15 \%$ in topsoil). ${ }^{33}$

236 Table S1 shows the summary statistics of all measured variables in the leachates collected by the 237 wicks at $45 \mathrm{~cm}$ and $100 \mathrm{~cm}$ depth. Forty-seven per cent of the $\mathrm{P}$ concentration data are below the 238 limit of quantification (LOQ). A correlation analysis (Table S5) shows that the $\mathrm{P}$ concentration is 239 most strongly and positively associated with those of Fe and $\mathrm{Mn}$. In the last drainage season, the 
$240 \mathrm{Al}$ concentration was measured and correlates positively with that of $\mathrm{Fe}(\mathrm{r}=+0.83$; log-log scale;

$241 \mathrm{p}<0.0001)$ and P (Table S5). Moreover, both the concentrations of Mn and Fe decrease with

242 increasing concentration of $\mathrm{SO}_{4}{ }^{2-}$ and $\mathrm{NO}_{3}^{-}$(Figure S5). In addition, in June 2016, a Mn and P

243 peak in the leachates coincides with a period of large volumetric moisture content and high

244 temperatures (T) (Figure S6). Birnessite $\left(\mathrm{MnO}_{2}\right)$ and $\mathrm{Fe}(\mathrm{III})$ and $\mathrm{Al}$ oxyhydroxides are insoluble

245 in oxic conditions at neutral $\mathrm{pH}^{42,43}$ Therefore, the positive correlations between the

246 concentrations of $\mathrm{Mn}, \mathrm{Fe}, \mathrm{P}$ and $\mathrm{Al}$ suggest that reductive dissolution of $\mathrm{Mn}$ (III,IV) and/or Fe(III)

247 occurs and that thereby colloidal $\mathrm{Al}(\mathrm{OH})_{3}$ and $\left.\mathrm{Fe}(\mathrm{OH})_{3}\right)$ and associated $\mathrm{P}$ are released, which is

248 similar to previous findings under experimentally varied redox conditions. ${ }^{18,20}$ Nitrate, and even

249 sulphate, may act as electron acceptor in subsoil in anaerobic conditions and that may explain the

250 negative correlation with the concentrations of Mn and Fe. Furthermore, a seasonal trend is

251 detected: leaching starts usually in December, typically with high P concentrations, the P

252 concentrations are lowest in the months January-March and increase again from March-June, until

253 no more water is leached into the wicks (example in Figure S6). This trend follows the observed

254 temperatures and is similar to the seasonality observed in $\mathrm{CaCl}_{2}$ extracts from another soil. ${ }^{36}$

255 Microbial respiration of organic matter increases with temperature and supplies electrons that may

256 trigger anaerobic reductions once $\mathrm{O}_{2}$ is depleted. ${ }^{22}$ This might explain the observed seasonality.

257 Overall, the wick leachates suggest that $\mathrm{P}$ release is triggered by reducing conditions.

258 The soil core sampling and analysis campaign corroborates that anaerobic respiration occurs in 259 situ. Table S6 and Table S7 provide soil properties and the correlation table. The elements present 260 in the $0.45-\mu \mathrm{m}$-filtered $1 \mathrm{mM} \mathrm{CaCl} 2$ extracts of soil are defined here as "total 'dissolved' 261 elements", these include both truly dissolved and colloidal elements as defined above (section 2.2).

262 The total 'dissolved' Mn concentrations $(<0.45 \mu \mathrm{m})$ range $0.007-5 \mu \mathrm{M}$ and generally peak in soil 
263 samples of the plough pan, the same is true for corresponding P concentrations (Figure 1). Overall,

264 little $\mathrm{Fe}(\mathrm{II})$ is detected in the extracts: the $90^{\text {th }}$ percentile is $1.1 \mu \mathrm{M}$ and only 15 samples $(\mathrm{n}=105)$

265 have an $\mathrm{Fe}$ (II) concentration above the LOQ, i.e. $0.52 \mu \mathrm{M}$ ( 8 of these 15 correspond to the farmyard

266 manure treatment, see section 3.4). Anaerobic respiration is expected at a large water-filled pore

267 space (WFP), large organic carbon (OC) content and at low pH. At soil sampling, the average WFP

268 (estimated from the measured gravimetric water content, average bulk densities and the volumetric

269 water contents at saturation for each depth layer ${ }^{37,44}$ ) was $80 \%$ in the plough layer while that was

$27095 \%$ in the plough pan $(28-35 \mathrm{~cm}), 87 \%$ in the $35-45 \mathrm{~cm}$ layer and $88-100 \%$ in the other layers.

271 Hence, soil compaction significantly increased the WFP in the plough pan as compared to the

272 plough layer (Tukey HSD, $\mathrm{p}<0.05$ ). The type of organic amendment had no significant effect on

273 the estimated WFP (Tukey HSD, $p>0.05$ ). For all treatments, the OC content decreases with depth

274 and ranges from 1 to $18 \mathrm{~g} \mathrm{C} \mathrm{kg}^{-1}$. A multivariate model, using OC content and WFP as input,

275 largely explains total 'dissolved' $\mathrm{Mn}(<0.45 \mu \mathrm{m})$ concentrations $\left(\log _{10}(\mathrm{Mn}, \mu \mathrm{M})=-2.7+\right.$

$\left.2761.9 \log 10\left(\mathrm{OC}, \mathrm{gC} \mathrm{kg}^{-1}\right)+0.8 \mathrm{WFP} ; \mathrm{R}^{2}=0.82\right)$ and both OC and WFP have a significant effect $(\mathrm{p}<$

277 0.05) The $\mathrm{pH}$ had no significant effect, likely as there is little $\mathrm{pH}$ variation among the samples

278 (Table S6). Large OC content and large WFP co-occur in, and below the plough pan, giving rise

279 to the peak in total 'dissolved' $M n(<0.45 \mu \mathrm{m})$ concentrations in those layers (Table 1, Figure 1).

280 The good model fit, the significant effect of both OC content and WFP and the location of Mn

281 solubilisation in the profile suggest that reductive dissolution of Mn oxyhydroxides occurs. The

282 total 'dissolved' P concentrations $(<0.45 \mu \mathrm{m})$ exhibit a remarkably strong correlation with those

283 of Mn among all depths and treatments (Figure 2). Moreover high total 'dissolved' Fe(III) and Al

284 concentrations $(<0.45 \mu \mathrm{m})$ are present where high total 'dissolved' Mn concentrations $(<0.45$

$285 \mu \mathrm{m}$ ) are found and $\mathrm{Fe}(\mathrm{III})$ and $\mathrm{Al}$ are highly positively correlated (Figure S7). At $\mathrm{pH}$ values 
between 6.4 and 7.6, Fe(III) and Al are likely present as mineral Fe and Al colloids because of the

287 low true solubility of $\mathrm{Fe}^{3+}$ and $\mathrm{Al}^{3+}$ and their inorganic complexes in natural waters and the low $288 \mathrm{Fe}^{3+}$ and $\mathrm{Al}^{3+}$ complexation capacity by dissolved organic matter at neutral $\mathrm{pH} .{ }^{3,10,42}$ The high $289 \mathrm{Fe}(\mathrm{III})-\mathrm{Al}$ correlation also suggests that $\mathrm{Fe}(\mathrm{III})$ is released as colloids rather than as dissolved $\mathrm{Fe}^{2+}$ 290 through reductive dissolution. ${ }^{7,10,18}$ Total 'dissolved' $\mathrm{P}(<0.45 \mu \mathrm{m})$ logically rises as the degree of 291 phosphate saturation of the soil rises (Figure 2) i.e. as $\mathrm{P}_{\mathrm{Ox}} / 0.5\left(\mathrm{Fe}_{\mathrm{Ox}}+\mathrm{Al}_{\mathrm{Ox}}\right)$ increases with subscript

292 Ox referring to oxalate extraction. The soil extract data hence suggests that not only Mn, but also $293 \mathrm{P}, \mathrm{Fe}(\mathrm{III})$ and $\mathrm{Al}$ are mobilised where anaerobic conditions occur.

\subsection{Waterlogged incubations confirm that anaerobic respiration mobilises phosphorus and}

manganese

297 During the waterlogged soil incubations, the concentrations of inorganic carbon (IC) increased and 298 indicate soil respiration. The respiration rate increased with increasing OC content of the sample.

299 After one month of incubation, this resulted in an average cumulative microbial respiration of 19

$300 \pm 8 \mathrm{mmol} \mathrm{C} \mathrm{kg}^{-1}$ (mean \pm standard deviation) for the $28-45 \mathrm{~cm}$ depth layers and $2.6 \pm 1.6 \mathrm{mmol} \mathrm{C}$

$301 \mathrm{~kg}^{-1}$ for the deeper layers with little OC. Due to waterlogging of the $28-45 \mathrm{~cm}$ depth layers, 302 denitrification started and reductive Mn dissolution occurred (Figure 3). Total 'dissolved' Mn (< $3030.45 \mu \mathrm{m}$ ) was released up to concentrations of more than $100 \mu \mathrm{M}$, about factor 60 above what was 304 found in fresh soil extracts from corresponding samples of the field (contrast Figure 3 and Table 305 1). Total 'dissolved' $\mathrm{Mn}(<0.45 \mu \mathrm{m})$ was generally present as truly dissolved $\mathrm{Mn}(<10-12 \mathrm{kDa}$; 306 Figures 4 and S8), i.e. confirming reduction of $\mathrm{Mn}(\mathrm{IV})$ oxyhydroxides to ionic $\mathrm{Mn}^{2 / 3+}$. Figure 3 307 shows that reductive dissolution of Mn increases with increasing cumulative respiration and with 308 decreasing $\mathrm{pH}$ (i.e. faster $\mathrm{Mn}$ release for Min $\mathrm{N}$ treatment with initial $\mathrm{pH}$ of 6.5 vs. 7.0 for FYM 
and $\mathrm{BIO})$ as expected from redox theory. Total 'dissolved' $\mathrm{Fe}(<0.45 \mu \mathrm{m})$ but not truly dissolved

$310 \mathrm{Fe}(<12 \mathrm{kDa})$ increases with increased respiration unless after prolonged respiration (final samples;

311 Figure 4). Anaerobic respiration triggered a $\mathrm{P}(<0.45 \mu \mathrm{m})$ release but only for the soils with

312 sufficient OC to boost respiration and with a sufficient P status (i.e. 'FYM 28-45 cm', 'BIO 28-45

$313 \mathrm{~cm}$, Figure 3$)$ and the P release linearly related to the Mn release $(\mathrm{p}<0.0001)$. A detailed view

314 on the P release and its size fraction shows that mostly colloidal P (i.e. $<0.45 \mu \mathrm{m}$ and $>12 \mathrm{kDa}$ )

315 was released and this coincides with the release of colloidal Fe $\left(\log _{10}\left([\mathrm{P}]_{0.45}-[\mathrm{P}]_{12 \mathrm{kDa}}\right)=-0.2+\right.$

$\left.3160.8 \log _{10}\left([\mathrm{Fe}]_{0.45}-[\mathrm{Fe}]_{12 \mathrm{kDa}}\right) ; \mathrm{p}<0.0001\right)$. The release of truly dissolved $\mathrm{P}(<12 \mathrm{kDa})$, likely ionic

317 P or small dissolved organic $\mathrm{P}$, was only found at the final stage of the incubation after prolonged

318 respiration. The incubations of deeper soil layers, with little OC (in contrast to the topsoil samples),

319 showed no reductive release of Mn nor Fe: total 'dissolved' $\mathrm{Mn}(<0.45 \mu \mathrm{m})$ remained below 1

$320 \mu \mathrm{M}$ and total 'dissolved' Fe was $13 \pm 10 \mu \mathrm{M}$ (standard deviation) and did not increase with

321 respiration (data not shown).

\subsection{Application of labile organic matter favours reductive $P$ mobilisation}

324 Table 1 shows how total 'dissolved' $\mathrm{P}, \mathrm{Mn}, \mathrm{Fe}(\mathrm{II}), \mathrm{Fe}(\mathrm{III})$ and $\mathrm{Al}(<0.45 \mu \mathrm{m})$ in the $\mathrm{CaCl}_{2}$ extracts

325 of the soil relate to the different organic fertiliser applications. The 19 years applications of

326 farmyard manure (FYM) and of municipal solid waste compost (MSW) enhanced total 'dissolved'

$327 \mathrm{Mn}, \mathrm{Fe}(\mathrm{III})$ and $\mathrm{Al}(<0.45 \mu \mathrm{m})$ in the subsoil compared to corresponding elements at

328 corresponding depths in the mineral $\mathrm{N}$ treatment (MIN N) treatment. The different organic

329 fertilisers were added on an equal $\mathrm{C}$ basis, thus the $\mathrm{OM}$ quality may matter. The composting

330 process of the MSW involved a short or sometimes lacking maturation phase, in contrast to the 
331 BIO and GWS composts, leading to a larger biodegradability for the first. ${ }^{35}$ Compost is a more

332 decomposed and stable product than farmyard manure. Thus, farmyard manure likely introduces

333 more labile OM that can leach and spark reductive processes in the subsoil. Therefore, the MSW

334 and FYM likely enhanced more Fe(III) and Mn(II,IV) reducing reactions in the subsoil than the

335 more stable composts (BIO and GWS). This coincides with higher total 'dissolved' P $(<0.45 \mu \mathrm{m})$

336 as well. Colloid-mediated $\mathrm{P}$ leaching was previously suggested to explain the higher $\mathrm{P}$

337 concentrations in column leachates for FYM than that for BIO, despite the two times larger net P

338 balance for the latter. ${ }^{3}$ The $\mathrm{Mn}$ and Fe(III) concentrations in the $90-100 \mathrm{~cm}$ depth layers are

339 significantly higher for FYM as compared to that for BIO.The data of GWS with high total

340 'dissolved' P concentrations $(<0.45 \mu \mathrm{m})$ obviously deviate from the trend because of the excess

341 P that was added in the GWS treatment (Table 1).

342 3.5 Discrepancy between wicks and extracts: artificial oxidation

343 The concentrations of $\mathrm{P}, \mathrm{Fe}, \mathrm{Al}$ and $\mathrm{Mn}$ in the $1 \mathrm{mM} \mathrm{CaCl}_{2}$ extracts of field-moist soils, sampled

344 from the 35-45 cm layers (near the wick sampler depth), are orders of magnitude larger than those

345 measured in the wick samplers of corresponding treatments and sampling time at $45 \mathrm{~cm}$ depth

346 (Table S8). The leachates are stored in tanks and pumped out twice a month and colloid

347 aggregation and/or sedimentation on the tank bottom may occur. Other wick samplers had been

348 removed in 2010 and were clearly loaded with colloids after about 6 years of use (as shown by a

349 reddish colour on the wicks). The Ca concentration in the $\mathrm{CaCl}_{2}$ extracts of field-moist soil ranged

350 0.97-1.3 mM (measured after extraction; $\mathrm{P}_{10}-\mathrm{P}_{90}$ ) while wick leachates $\mathrm{Ca}^{2+}$ ranged 1-4. This

351 difference in $\mathrm{Ca}^{2+}$ concentration is not fully explaining the difference in $\mathrm{Fe}$ and $\mathrm{Al}$ between wicks

352 and extracts. For the MIN N treatment, for example, there is no difference in the Ca concentration

353 between the soil extracts and the wick samples, but still a factor six difference in that of P, 23 in 
354 that of $\mathrm{Fe}, 38$ in that of $\mathrm{Al}$ and 14 in that of Mn. Most likely, wick samplers introduce sampling

355 artefacts and do not reflect the in situ (redox) state. Artificial oxidation of $\mathrm{Fe}^{2+}$ and $\mathrm{Mn}^{2 / 3+}$ and

356 retention of colloids/particles might occur in the wicks. This does, however, not imply that the

$357 \mathrm{CaCl}_{2}$ extracts offer a single true representation of the soil solution that is free from artefacts (see

358 also section SI S2).

\section{$359 \quad 3.6$ Environmental significance}

360 Taken together, this study provides multiple lines of evidence for anaerobic respiration and

361 reduction of $\mathrm{Mn}(\mathrm{IV})$ oxyhydroxides, even in a relatively well-drained unsaturated soil, and that

362 this enhances the mobilisation of $\mathrm{P}$. This $\mathrm{P}$ mobilisation is likely as colloidal $\mathrm{P}$ as demonstrated in

363 the laboratory conditions. We have additionally calculated the speciation of $\mathrm{P}$ in the soil extracts

364 of the field (details not shown) using methods and assumption that we previously described. ${ }^{3}$ This

365 calculation showed that $\mathrm{P}$ is mainly colloidal-bound on the $\mathrm{Fe}(\mathrm{III})$ and $\mathrm{Al}$ mineral colloids. Hence,

366 the data suggest that $\mathrm{Mn}$ reduction triggers the release of colloidal $\mathrm{Al}$ and $\mathrm{Fe}(\mathrm{III})$ that, in turn, is

367 able to act as a mobile P-vector. Reductive dissolution of Fe(III), releasing ionic $\mathrm{P}$, might also be

368 involved as shown by (1) a limited number of enhanced Fe(II) concentrations, e.g. under FYM

369 (Table 1) and (2) the incubation experiment at prolonged respiration (Figure 4). In addition, Fe(III)

370 reduction in the microsites (inside aggregates) might release Fe(II) that is subsequently oxidised

371 in larger, oxygen-rich pores (between aggregates), forming colloidal Fe(III). Moreover, it cannot

372 be excluded that oxidation of Fe(II) to Fe(III) upon sampling and soil extraction under ambient

373 conditions occurs. Long-term application of labile and mobile organic matter stimulates reductive

374 P release where the WFP is larger, e.g. in the compacted plough pan. Modelling P transport in soil

375 is now required to identify to what extent reductive $\mathrm{P}$ mobilisation contributes to accelerated

376 leaching beyond what is to be expected based on the local sorption equilibrium assumption with 
377 no redox related processes. The link between redox cycling and $\mathrm{P}$ solubility should be considered

378 to fully understand the dynamics of $\mathrm{P}$ in saturated and unsaturated agricultural soil and its vertical

379 P migration towards groundwater. 


\section{Corresponding Author}

382 Phone: +32 163770 33; e-mail: ruben.warrinnier@,kuleuven.be

\section{Author Contributions}

385 The manuscript was written through the contributions of all authors. All authors have given 386 approval of the final version of the manuscript.

\section{$387 \quad$ Funding}

388 FWO (Research Foundation Flanders): strategic basic research grant.

$389 \quad$ Notes

390 The authors declare no competing financial interest.

391 ACKNOWLEDGMENTS

392 Thanks to J.-C. Gueudet, the ECOSYS team, all colleagues (especially S. Ysabie) of the Division 393 of Soil and Water Management (KU Leuven). Thanks to Wantana Klysubun and her team at BL-

394 8, SLRI, Thailand for professional help with P K-edge XANES analysis. The QualiAgro field 395 experiment is part of the SOERE-PRO (network of long-term experiments dedicated to the study 396 of impacts of OM recycling), integrated as a service of the "Investment in the Future" infrastructure 397 AnaEE-France, overseen by the French National Research Agency (ANR-11-INBS-0001). It has 398 been founded and is still supported by INRA and Veolia R\&I. Thanks to T. Driessens. 
401 Section S1 The Qualiagro field experiment and wick samplers (Figure S1, Table S1)

402 Section $\mathbf{S 2}$ Test for potential oxidation during soil handling and $\mathrm{CaCl}_{2}$ extraction on field-moist 403 soil. (Table S2, Figure S2)

404 Section S3 P K-edge XANES spectroscopy. (Figure S3, Figure S4, Table S3)

405 Section S4 Correction factor waterlogged soil incubations

406 Table S4 Selected average soil properties.

407 Table S5 Correlation analyses wick data.

408 Figure S5 Correlations between Fe and Mn versus nitrate and sulphate in the wick samples.

409 Figure S6 Mn and P concentrations peak in wick leachates in June 2016 at high temperature and 410 moisture content.

411 Table S6 Summary statistics of the soil properties (all depths \& treatments).

412 Table S7 Correlation analyses soil properties.

413 Figure S7 Total 'dissolved' Fe(III) vs. Al and Fe(III)+Al vs. Mn

414 Figure S8 Total 'dissolved' Mn $(<0.45 \mu \mathrm{m})$ vs. Truly dissolved Mn $(<12 \mathrm{kDa})$.

415 Table S8 Comparison between solutes measured in wicks and $\mathrm{CaCl}_{2}$ extracts.

416 This information is available free of charge via the internet at http://pubs.acs.org. 

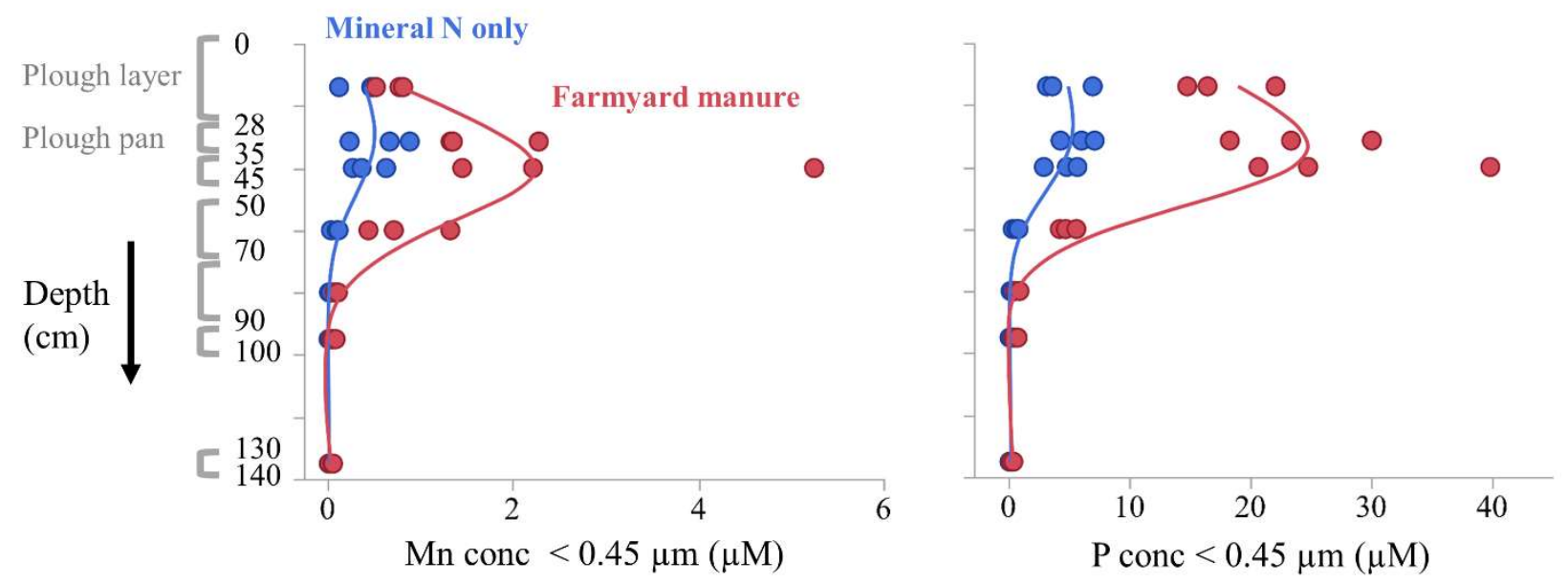

Figure 1 Soil depth profiles of $\mathrm{Mn}$ and $\mathrm{P}$ concentrations in field-moist soil extracts $(1 \mathrm{mM} \mathrm{CaCl}, 0.45$ - $\mu \mathrm{m}$-filtered $)$ show that both are mobilised in and below the compacted plough pan $(28-35 \mathrm{~cm})$, where large organic carbon (OC) content and large water-filled pore space co-occur. The shown profiles are those of field plots amended with mineral $\mathrm{N}$ and farmyard manure for 19 years, the other treatments yield similar trends. Trend lines are shown to guide the eye. 

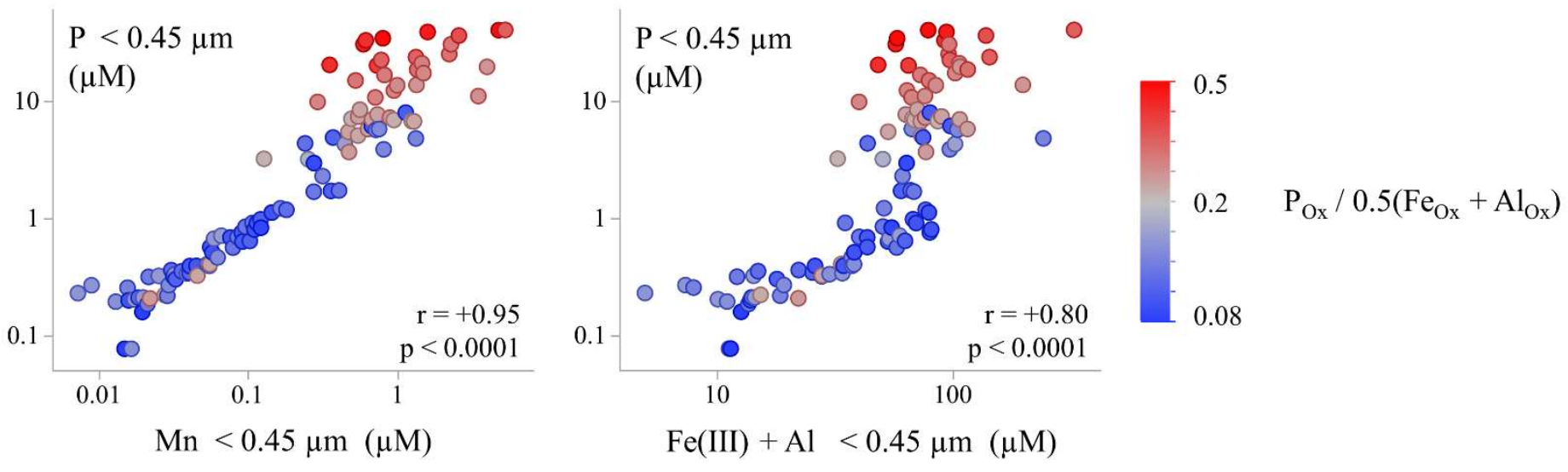

Figure 2 The correlations among $\mathrm{P}, \mathrm{Mn}$, and $\mathrm{Fe}(\mathrm{III})+\mathrm{Al}$ concentrations in field-moist soil extracts $(1 \mathrm{mM} \mathrm{CaCl} 2,0.45-\mu \mathrm{m}-\mathrm{filtered})$ of all samples, i.e. all depths and soil treatments. High Mn concentrations indicate anaerobic conditions, Fe(III) and Al likely occur as colloids that bind $\mathrm{P}$ (see text). The $\mathrm{P}$ mobilisation also depends on the internal loading of the soil, i.e. the degree of phosphate saturation, i.e. $\mathrm{P}_{\mathrm{Ox}} / 0.5\left(\mathrm{Fe}_{\mathrm{Ox}}+\mathrm{Al}_{\mathrm{Ox}}\right)$ with ox referring to oxalate extraction. Note that molar $\mathrm{P}$ concentrations are about one order of magnitude larger than those of $\mathrm{Mn}$, excluding the possibility for $\mathrm{P}$ being bound to colloidal $\mathrm{Mn}$ mineral particles. 


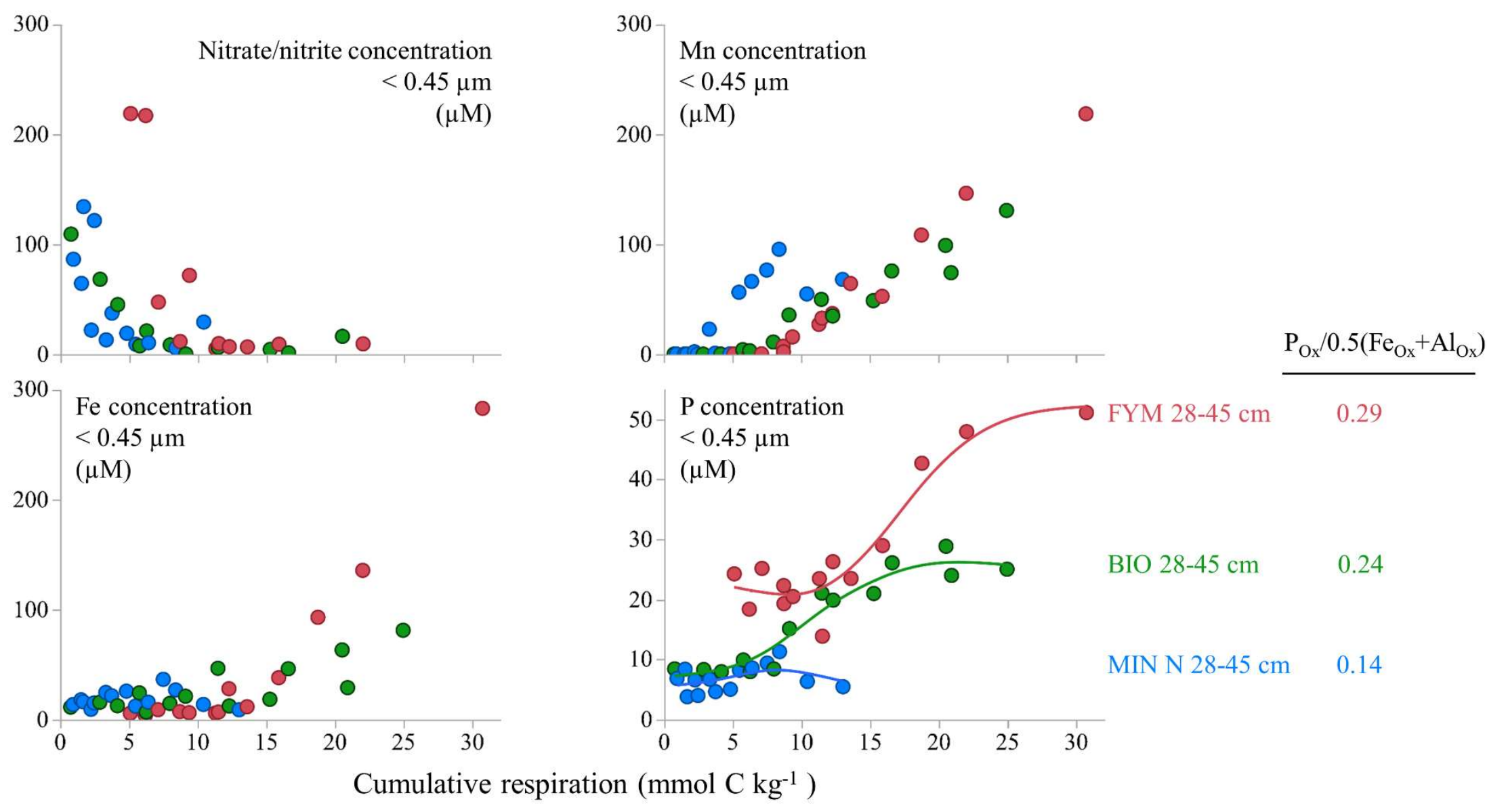

Cumulative respiration $\left(\mathrm{mmol} \mathrm{C} \mathrm{kg}^{-1}\right)$

431 Figure 3 Sequential redox reactions and phosphorus release during anoxic incubation of the $28-45 \mathrm{~cm}$ depth layers (1 to 30 days) in waterlogged conditions ( 1 to 30 days; $5 \mathrm{~L} \mathrm{~kg}^{-1} ; 1 \mathrm{mM} \mathrm{CaCl}_{2}$ that was not deoxygenated) at $20{ }^{\circ} \mathrm{C}$. Once all oxygen and nitrate $\left(\mathrm{NO}_{3}\right)$ is 433 consumed, total 'dissolved' $\mathrm{Mn}, \mathrm{Fe}$ and $\mathrm{P}$ concentrations $(<0.45 \mu \mathrm{m})$ are released but only for the soils with large $\mathrm{P}$ loading $434\left(\mathrm{P}_{\mathrm{Ox}} / 0.5\left(\mathrm{Fe}_{\mathrm{Ox}}+\mathrm{Al}_{\mathrm{Ox}}\right)\right)$ and large respiration. Trend lines are shown to guide the eye. 
FYM $28-45 \mathrm{~cm}$
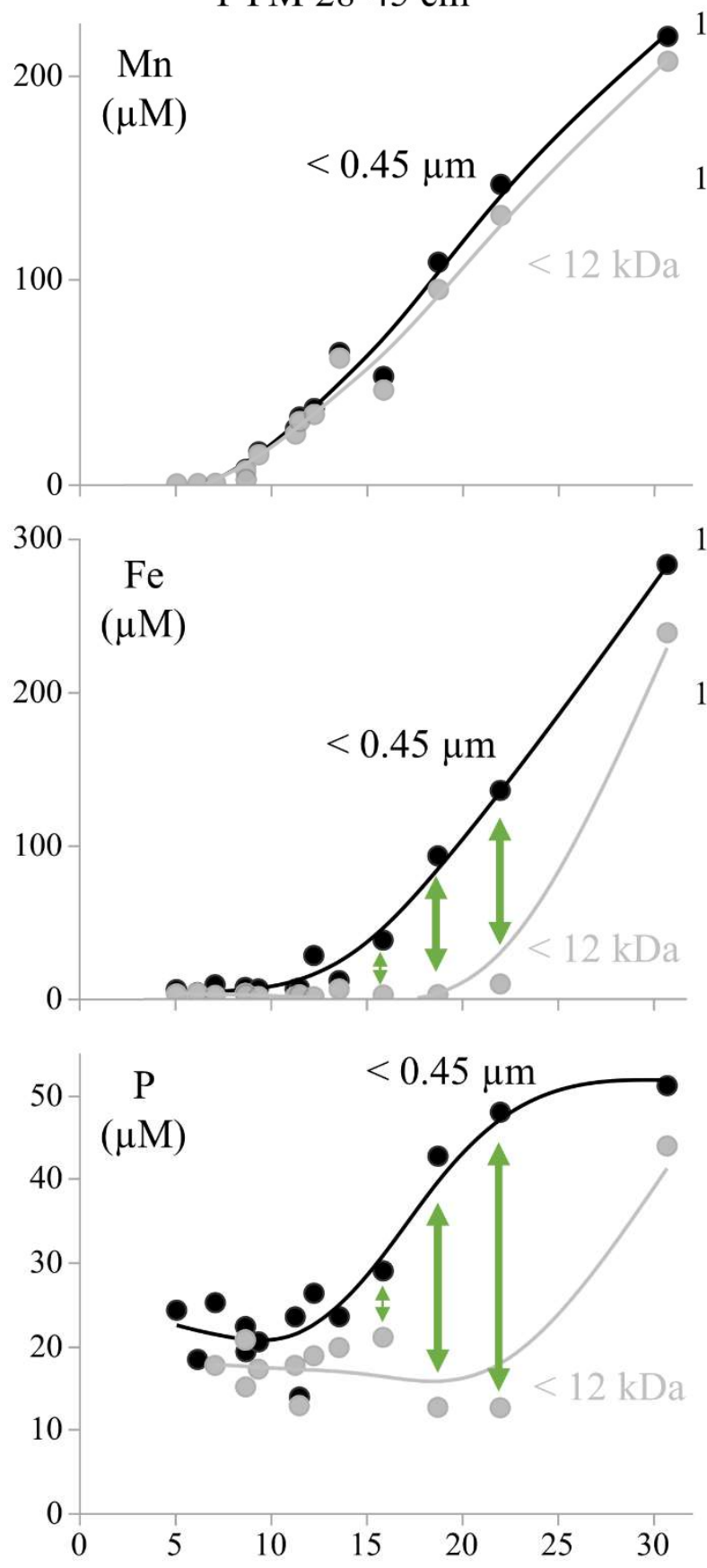

BIO 28-45 cm
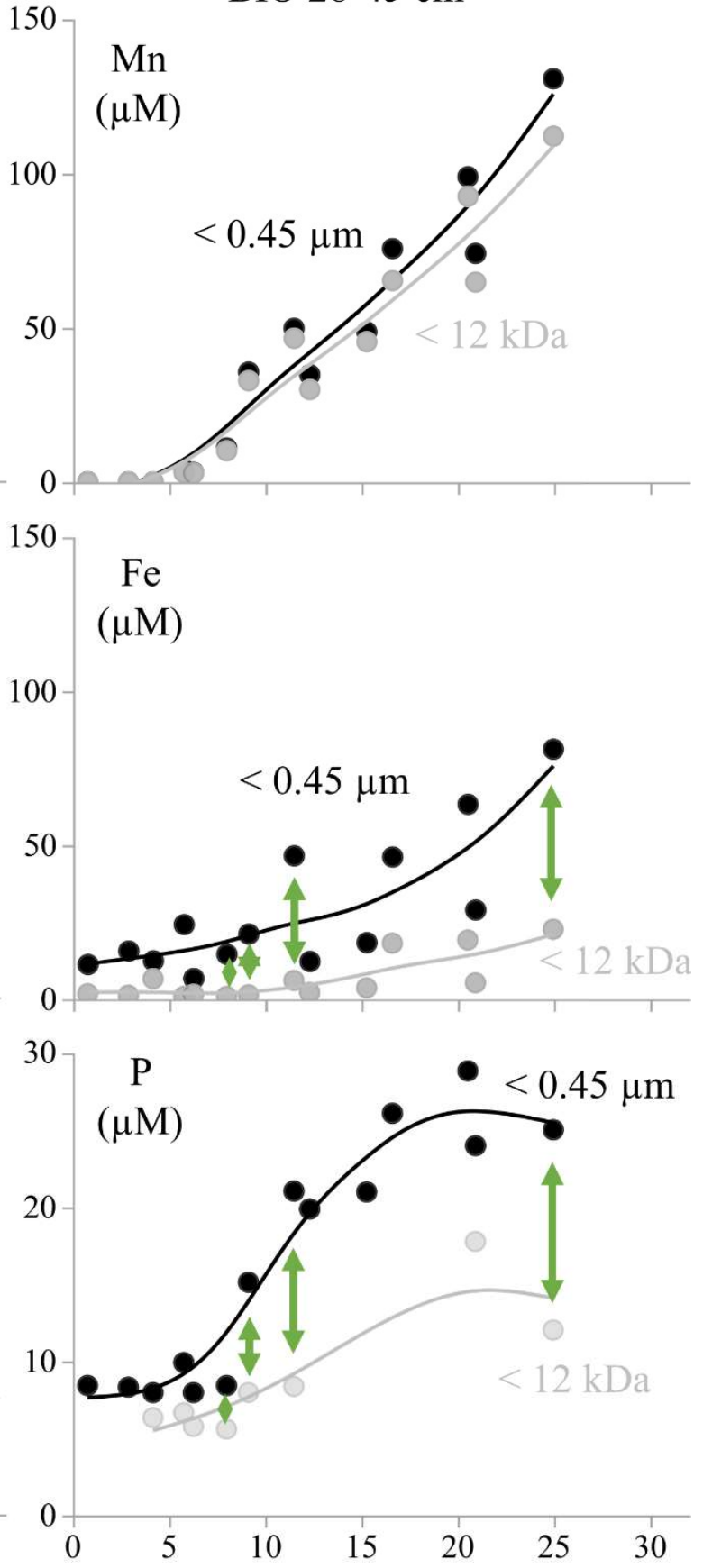

435

\section{Cumulative respiration ( $\mathrm{mmol} \mathrm{C} \mathrm{kg}{ }^{-1}$ )}

Figure 4 The release and size fractionation of Mn, Fe, and P upon anaerobic respiration of the 'FYM 28$45 \mathrm{~cm}$ ' and 'BIO 28-45 cm' samples. During the initial phases of Mn and Fe release, mostly colloidal P ( $<$ $0.45 \mu \mathrm{m} ;>10-12 \mathrm{kDa})$ is released. Black points are total 'dissolved' concentrations $(<0.45 \mu \mathrm{m})$, grey points are 10-12 $\mathrm{kDa}$ dialysed concentrations and the difference is indicated by the green double arrow, i.e. colloidal concentrations. Trend lines are shown to guide the eye. For the first time point for 'FYM 28-45 $\mathrm{cm}$ ' and for the first, fifth and sixth time point for 'BIO $28-45 \mathrm{~cm}$ ', dialyzable $\mathrm{P}$ could not be determined due to a $\mathrm{P}$ contamination in the dialysates. 
443 Table 1 Treatment effects on the total 'dissolved' $(<0.45 \mu \mathrm{m})$ concentrations of $\mathrm{P}, \mathrm{Mn}, \mathrm{Fe}(\mathrm{II}), \mathrm{Fe}(\mathrm{III})$ 444 and $\mathrm{Al}$ in the $1 \mathrm{mM} \mathrm{CaCl}_{2}$ extracts of field-moist soils. Means and standard errors (SE) are presented $445(\mathrm{n}=3)$. Significant differences between treatments are indicated with capital letters (Tukey HSD test, $446 \mathrm{p}<0.05)$ when tested at corresponding depths. Bold values denote concentrations exceeding the 447 corresponding control (MIN N). Logically, a large degree of phosphate saturation (DPS, Table S4) 448 results in elevated $\mathrm{P}$ concentrations, e.g. GWS treatment with the largest P balance*.

\begin{tabular}{|c|c|c|c|c|c|c|c|c|c|c|c|}
\hline \multirow{3}{*}{\multicolumn{2}{|c|}{$\begin{array}{r}\text { P balance }{ }^{*} \\
\left(\mathrm{~kg} \mathrm{P} \mathrm{ha}^{-1} \text { year }^{-1}\right)\end{array}$}} & \multicolumn{10}{|c|}{ Treatment } \\
\hline & & \multicolumn{2}{|c|}{ MIN N } & \multicolumn{2}{|c|}{ MSW } & \multicolumn{2}{|c|}{ FYM } & \multicolumn{2}{|c|}{$\mathrm{BIO}$} & \multicolumn{2}{|c|}{ GWS } \\
\hline & & \multicolumn{2}{|c|}{-23} & \multicolumn{2}{|c|}{-2.8} & \multicolumn{2}{|c|}{11} & \multicolumn{2}{|l|}{20} & \multicolumn{2}{|c|}{85} \\
\hline Element & $\begin{array}{l}\text { depth } \\
(\mathrm{cm})\end{array}$ & mean & SE & mean & SE & mean & SE & mean & SE & mean & $\mathrm{SE}$ \\
\hline \multirow{7}{*}{$\begin{array}{c}{[\mathrm{P}]} \\
(\mu \mathrm{M})\end{array}$} & $0-28$ & $4.6^{\mathrm{D}}$ & 1.2 & $6.5^{\mathrm{C}, \mathrm{D}}$ & 0.57 & $18^{\mathrm{A}, \mathrm{B}}$ & 2.2 & $11^{\mathrm{B}, \mathrm{C}}$ & 0.71 & $28^{A}$ & 4.1 \\
\hline & $28-35$ & $5.8^{\mathrm{C}}$ & 0.82 & $6.4^{\mathrm{C}}$ & 0.75 & $24^{\mathrm{A}, \mathrm{B}}$ & 3.4 & $14^{\mathrm{B}}$ & 1.8 & $31^{\mathrm{A}}$ & 5.8 \\
\hline & $35-45$ & $4.5^{\mathrm{A}}$ & 0.82 & $6.7^{\mathrm{A}}$ & 0.63 & $29^{\mathrm{A}}$ & 5.8 & $13^{\mathrm{A}}$ & 3.6 & $26^{\mathrm{A}}$ & 11 \\
\hline & $50-70$ & $0.60^{\mathrm{B}}$ & 0.14 & $1.9^{\mathrm{A}, \mathrm{B}}$ & 0.19 & $4.9^{\mathrm{A}}$ & 0.40 & $1.3^{\mathrm{A}, \mathrm{B}}$ & 0.16 & $4.4^{\mathrm{A}}$ & 2.2 \\
\hline & $70-90$ & $0.23^{\mathrm{B}}$ & 0.05 & $0.92^{\mathrm{A}}$ & 0.13 & $0.69^{A}$ & 0.10 & $0.51^{\mathrm{A}, \mathrm{B}}$ & 0.14 & $0.62^{\mathrm{A}, \mathrm{B}}$ & 0.14 \\
\hline & $90-100$ & $0.16^{\mathrm{C}}$ & 0.04 & $0.64^{\mathrm{A}}$ & 0.04 & $0.55^{\mathrm{A}, \mathrm{B}}$ & 0.11 & $0.27^{\mathrm{A}, \mathrm{B}, \mathrm{C}}$ & 0.04 & $0.26^{\mathrm{B}, \mathrm{C}}$ & 0.03 \\
\hline & $130-140$ & 0.20 & 0.07 & 0.35 & 0.03 & 0.34 & 0.08 & 0.29 & 0.05 & 0.23 & 0.02 \\
\hline \multirow{7}{*}{$\begin{array}{c}{[\mathrm{Fe}(\mathrm{II})]} \\
(\mu \mathrm{M})\end{array}$} & $0-28$ & 0.60 & 0.34 & $<0.52$ & - & $<0.52$ & - & $<0.52$ & - & $<0.52$ & - \\
\hline & $28-35$ & $<0.52$ & - & 1.4 & 1.1 & 1.1 & 0.86 & $<0.52$ & - & 0.70 & 0.44 \\
\hline & $35-45$ & $<0.52$ & - & 1.2 & 0.73 & 2.2 & 1.91 & $<0.52$ & - & 0.40 & 0.14 \\
\hline & $50-70$ & $<0.52$ & - & $<0.52$ & - & 5.4 & 4.4 & $<0.52$ & - & $<0.52$ & - \\
\hline & $70-90$ & $<0.52$ & - & $<0.52$ & - & 0.46 & 0.20 & $<0.52$ & - & $<0.52$ & - \\
\hline & $90-100$ & $<0.52$ & - & $<0.52$ & - & 0.46 & 0.20 & $<0.52$ & - & $<0.52$ & - \\
\hline & $130-140$ & $<0.52$ & - & $<0.52$ & - & 0.82 & 0.28 & $<0.52$ & - & $<0.52$ & - \\
\hline \multirow{7}{*}{$\begin{array}{l}{[\mathrm{Mn}]} \\
(\mu \mathrm{M})\end{array}$} & $0-28$ & 0.37 & 0.12 & 0.65 & 0.15 & 0.71 & 0.09 & 0.65 & 0.19 & 0.58 & 0.13 \\
\hline & $28-35$ & 0.60 & 0.19 & 0.86 & 0.22 & 1.7 & 0.31 & 2.0 & 0.76 & 2.0 & 1.4 \\
\hline & $35-45$ & 0.43 & 0.11 & 1.1 & 0.15 & 3.0 & 1.2 & 2.0 & 1.0 & 1.5 & 0.67 \\
\hline & $50-70$ & $0.09^{\mathrm{B}}$ & 0.02 & $0.36^{\mathrm{A}, \mathrm{B}}$ & 0.03 & $0.83^{\mathrm{A}}$ & 0.26 & $0.21^{\mathrm{A}, \mathrm{B}}$ & 0.03 & $0.49^{\mathrm{A}, \mathrm{B}}$ & 0.21 \\
\hline & $70-90$ & $0.03^{\mathrm{B}}$ & 0.01 & $0.11^{\mathrm{A}}$ & 0.02 & $0.10^{A}$ & 0.01 & $0.06^{\mathrm{A}, \mathrm{B}}$ & 0.02 & $0.07^{\mathrm{A}, \mathrm{B}}$ & 0.02 \\
\hline & $90-100$ & $0.02^{\mathrm{B}}$ & 0.002 & $0.06^{\mathrm{A}}$ & 0.003 & $0.06^{\mathrm{A}}$ & 0.01 & $0.03^{\mathrm{B}}$ & 0.01 & $0.02^{\mathrm{B}}$ & 0.002 \\
\hline & $130-140$ & $0.02^{\mathrm{A}, \mathrm{B}}$ & 0.003 & $0.04^{\mathrm{A}}$ & 0.01 & $0.05^{\mathrm{A}}$ & 0.01 & $0.04^{\mathrm{A}}$ & 0.01 & $0.01^{\mathrm{B}}$ & 0.002 \\
\hline \multirow{7}{*}{$\begin{array}{c}{[\mathrm{Fe}(\mathrm{III})]} \\
(\mu \mathrm{M})\end{array}$} & $0-28$ & 13 & 3.2 & 23 & 4.7 & 23 & 3.4 & 14 & 2.2 & 17 & 1.7 \\
\hline & $28-35$ & $16^{\mathrm{B}}$ & 0.48 & $21^{\mathrm{A}, \mathrm{B}}$ & 1.2 & $35^{\mathrm{A}}$ & 1.7 & $20^{\mathrm{A}, \mathrm{B}}$ & 2.2 & $27^{\mathrm{A}, \mathrm{B}}$ & 3.7 \\
\hline & $35-45$ & 15 & 4.1 & 25 & 3.7 & 53 & 17 & 28 & 7.0 & 37 & 14 \\
\hline & $50-70$ & 10 & 3.7 & 16 & 1.1 & 32 & 7.5 & 12 & 2.1 & 22 & 7.1 \\
\hline & $70-90$ & 4.4 & 2.5 & 24 & 5.1 & 17 & 3.1 & 9.3 & 5.5 & 11 & 2.8 \\
\hline & $90-100$ & $3.1^{\mathrm{B}}$ & 1.7 & $16^{\mathrm{A}}$ & 1.7 & $13^{\mathrm{A}}$ & 3.4 & $4.5^{\mathrm{B}}$ & 1.1 & $2.7^{\mathrm{B}}$ & 0.59 \\
\hline & $130-140$ & $2.9^{\mathrm{A}, \mathrm{B}}$ & 1.0 & $8.2^{\mathrm{A}}$ & 0.50 & $7.2^{\mathrm{A}}$ & 2.0 & $5.8^{\mathrm{A}}$ & 1.5 & $1.6^{\mathrm{B}}$ & 0.48 \\
\hline \multirow{7}{*}{$\begin{array}{l}{[\mathrm{Al}]} \\
(\mu \mathrm{M})\end{array}$} & $0-28$ & 46 & 10 & 48 & 6.1 & 60 & 8.0 & 44 & 6.4 & 37 & 1.3 \\
\hline & $28-35$ & 57 & 12 & 48 & 1.8 & 82 & 14 & 68 & 5.4 & 51 & 4.2 \\
\hline & $35-45$ & 69 & 12 & 52 & 3.0 & $1310^{1}$ & 60 & $1110^{1}$ & 23 & 57 & 12 \\
\hline & $50-70$ & 37 & 8.8 & 46 & 1.1 & $1110^{1}$ & 42 & 53 & 6.0 & 46 & 11 \\
\hline & $70-90$ & 16 & 5.3 & 42 & 5.6 & 43 & 2.7 & 31 & 15 & 26 & 5.5 \\
\hline & $90-100$ & $11^{\mathrm{B}}$ & 2.9 & $36^{\mathrm{A}}$ & 3.0 & $37^{\mathrm{A}}$ & 11 & $15^{\mathrm{A}, \mathrm{B}}$ & 3.0 & $8.5^{\mathrm{B}}$ & 1.3 \\
\hline & $130-140$ & $10^{\mathrm{A}, \mathrm{B}}$ & 1.0 & $22^{\mathrm{A}}$ & 1.2 & $21^{\mathrm{A}}$ & 5.6 & $19^{\mathrm{A}}$ & 4.9 & $5.9^{\mathrm{B}}$ & 1.3 \\
\hline
\end{tabular}

449 *The $\mathrm{P}$ balance was calculated from recorded $\mathrm{P}$ applications and crop P offtake with exported grains and residues. 


\section{REFERENCES}

(1) Jarvie, H. P.; Sharpley, A. N.; Spears, B.; Buda, A. R.; May, L.; Kleinman, P. J. A. Water Quality Remediation Faces Unprecedented Challenges from "Legacy Phosphorus." Environ. Sci. Technol. 2013, 47 (16), 8997-8998. https://doi.org/10.1021/es403160a.

(2) Weng, L.; Vega, F. A.; Van Riemsdijk, W. H. Competitive and Synergistic Effects in PH Dependent Phosphate Adsorption in Soils: LCD Modeling. Environ. Sci. Technol. 2011, 45, 8420-8428. https://doi.org/10.1021/es201844d.

(3) Warrinnier, R.; Goossens, T.; Amery, F.; Vanden Nest, T.; Verbeeck, M.; Smolders, E. Investigation on the Control of Phosphate Leaching by Sorption and Colloidal Transport : Column Studies and Multi-Surface Complexation Modelling. Appl. Geochemistry 2019, 100 (November 2018), 371-379. https://doi.org/10.1016/j.apgeochem.2018.12.012.

(4) Langmuir, D. Aqueous Environmental Chemistry; McConnin, R., Ed.; Pretice Hall, Inc.: New Jersy, 1997.

(5) Rubæk, G. H.; Kristensen, K.; Olesen, S. E.; Østergaard, H. S.; Heckrath, G. Phosphorus Accumulation and Spatial Distribution in Agricultural Soils in Denmark. Geoderma 2013, 209-210, 241-250. https://doi.org/10.1016/j.geoderma.2013.06.022.

(6) De Bolle, S.; De Neve, S.; Hofman, G. Rapid Redistribution of P to Deeper Soil Layers in P Saturated Acid Sandy Soils. Soil Use Manag. 2013, 29 (SUPPL.1), 76-82. https://doi.org/10.1111/j.1475-2743.2012.00426.x.

(7) Regelink, I. C.; Koopmans, G. F.; van der Salm, C.; Weng, L.; van Riemsdijk, W. H. Characterization of Colloidal Phosphorus Species in Drainage Waters from a Clay Soil 
Using Asymmetric Flow Field-Flow Fractionation. J. Environ. Qual. 2013, 42 (2), 464. https://doi.org/10.2134/jeq2012.0322.

(8) Siemens, J.; Ilg, K.; Lang, F.; Kaupenjohann, M. Adsorption Controls Mobilization of Colloids and Leaching of Dissolved Phosphorus. Eur. J. Soil Sci. 2004, 55 (2), 253-263. https://doi.org/10.1046/j.1365-2389.2004.00596.x.

(9) Beauchemin, S.; Simard, R. R.; Cluis, D. Forms and Concentration of Phosphorus in Drainage Water of Twenty-Seven Tile-Drained Soils. J. Environ. Qual. 1998, 27 (3), 721. https://doi.org/10.2134/jeq1998.00472425002700030033x.

(10) Baken, S.; Regelink, I. C.; Comans, R. N. J.; Smolders, E.; Koopmans, G. F. Iron-Rich Colloids as Carriers of Phosphorus in Streams: A Field-Flow Fractionation Study. Water Res. 2016, 99, 83-90. https://doi.org/10.1016/j.watres.2016.04.060.

(11) Cornu, S.; Samouëlian, A.; Ayzac, A.; Montagne, D. Soluble and Colloidal Translocation of Al, Fe, Si and Mn in an Artificially Drained French Retisol. Geoderma 2018, 330 (June), 193-203. https://doi.org/10.1016/j.geoderma.2018.05.032.

(12) Baken, S.; Moens, C.; Van Der Grift, B.; Smolders, E. Phosphate Binding by Natural Iron-

Rich Colloids in Streams. Water Res. 2016, 98, 326-333. https://doi.org/10.1016/j.watres.2016.04.032.

(13) Philippe, A.; Schaumann, G. E. C. Environ. Sci. Technol. 2014, 48 (16), 8946-8962. https://doi.org/10.1021/es502342r. 
Freshwaters. Aquat. Geochemistry 2008, 14 (4), 337-358. https://doi.org/10.1007/s10498008-9040-5.

493

494

495

496
(15) Smolders, E.; Baetens, E.; Verbeeck, M.; Nawara, S.; Diels, J.; Verdievel, M.; Peeters, B.; De Cooman, W.; Baken, S. Internal Loading and Redox Cycling of Sediment Iron Explain Reactive Phosphorus Concentrations in Lowland Rivers. Environ. Sci. Technol. 2017, 51 (5), 2584-2592. https://doi.org/10.1021/acs.est.6b04337.

(16) Gu, S.; Gruau, G.; Dupas, R.; Petitjean, P.; Li, Q.; Pinay, G. Respective Roles of FeOxyhydroxide Dissolution, PH Changes and Sediment Inputs in Dissolved Phosphorus Release from Wetland Soils under Anoxic Conditions. Geoderma 2019, 338 (June 2018), 365-374. https://doi.org/10.1016/j.geoderma.2018.12.034.

(17) Kirk, G. The Biogeochemistry of Submerged Soils; John Wiley \& Sons, Ltd: Chichester, UK, 2004. https://doi.org/10.1002/047086303X.

(18) Henderson, R.; Kabengi, N.; Mantripragada, N.; Cabrera, M.; Hassan, S.; Thompson, A. Anoxia-Induced Release of Colloid- and Nanoparticle-Bound Phosphorus in Grassland Soils. Environ. Sci. Technol. 2012, $46 \quad$ (21), 11727-11734. https://doi.org/10.1021/es302395r.

(19) Blackwell, M. S. A.; Brookes, P. C.; de la Fuente-Martinez, N.; Murray, P. J.; Snars, K. E.; Williams, J. K.; Haygarth, P. M. Effects of Soil Drying and Rate of Re-Wetting on Concentrations and Forms of Phosphorus in Leachate. Biol. Fertil. Soils 2009, 45 (6), 635643. https://doi.org/10.1007/s00374-009-0375-X.

(20) Thompson, A.; Chadwick, O. A.; Boman, S.; Chorover, J. Colloid Mobilization during Soil 
Iron Redox Oscillations. Environ. Sci. Technol. 2006, 40 (18), 5743-5749. https://doi.org/10.1021/es061203b.

514

(21) Gu, S.; Gruau, G.; Dupas, R.; Rumpel, C.; Crème, A.; Fovet, O.; Gascuel-Odoux, C.; Jeanneau, L.; Humbert, G.; Petitjean, P. Release of Dissolved Phosphorus from Riparian Wetlands: Evidence for Complex Interactions among Hydroclimate Variability, Topography and Soil Properties. Sci. Total Environ. 2017, 598 (November), 421-431. https://doi.org/10.1016/j.scitotenv.2017.04.028.

(22) Borch, T.; Kretzschmar, R.; Skappler, A.; Van Cappellen, P.; Ginder-Vogel, M.; Voegelin, A.; Campbell, K. Biogeochemical Redox Processes and Their Impact on Contaminant Dynamics. Environ. Sci. Technol. 2010, 44 (1), 15-23. https://doi.org/10.1021/es9026248.

(23) Madison, A. S.; Tebo, B. M.; Mucci, A.; Sundby, B.; Luther, G. W. Abundant Porewater Mn(III) Is a Major Component of the Sedimentary Redox System. Science (80-. ). 2013, 341 (6148), 875-878. https://doi.org/10.1126/science.1241396.

(24) Keiluweit, M.; Nico, P.; Harmon, M. E.; Mao, J.; Pett-Ridge, J.; Kleber, M. Long-Term Litter Decomposition Controlled by Manganese Redox Cycling. Proc. Natl. Acad. Sci. 2015, 112 (38), E5253-E5260. https://doi.org/10.1073/pnas.1508945112.

(25) Jones, M. E.; Nico, P. S.; Ying, S.; Regier, T.; Thieme, J.; Keiluweit, M. Manganese-Driven Carbon Oxidation at Oxic-Anoxic Interfaces. Environ. Sci. Technol. 2018, 52 (21), 1234912357. https://doi.org/10.1021/acs.est.8b03791.

(26) Gilkes, R. J.; McKenzie, R. M. Geochemistry and Mineralogy of Manganese in Soils. Manganese in Soils and Plants 1988, 1, 23-35. https://doi.org/10.1007/978-94-009-2817- 
534 (27) Gasparatos, D.; Massas, I.; Godelitsas, A. Fe-Mn Concretions and Nodules Formation in Redoximorphic Soils and Their Role on Soil Phosphorus Dynamics: Current Knowledge and Gaps. Catena 2019, 182 (June), 104106. https://doi.org/10.1016/j.catena.2019.104106.

(28) Keiluweit, M.; Wanzek, T.; Kleber, M.; Nico, P.; Fendorf, S. Anaerobic Microsites Have an Unaccounted Role in Soil Carbon Stabilization. Nat. Commun. 2017, 8 (1), 1-8. https://doi.org/10.1038/s41467-017-01406-6.

(30) Brewer, P. E.; Calderón, F.; Vigil, M.; von Fischer, J. C. Impacts of Moisture, Soil Respiration, and Agricultural Practices on Methanogenesis in Upland Soils as Measured with Stable Isotope Pool Dilution. Soil Biol. Biochem. 2018, 127 (February), 239-251. https://doi.org/10.1016/j.soilbio.2018.09.014.

547 (31) Keiluweit, M.; Nico, P. S.; Kleber, M.; Fendorf, S. Are Oxygen Limitations under

(32) Keiluweit, M.; Gee, K.; Denney, A.; Fendorf, S. Anoxic Microsites in Upland Soils Recognized Regulators of Organic Carbon Turnover in Upland Soils? Biogeochemistry 2016, 127 (2-3), 157-171. https://doi.org/10.1007/s10533-015-0180-6. Dominantly Controlled by Clay Content. Soil Biol. Biochem. 2018, 118 (December), 4250. https://doi.org/10.1016/j.soilbio.2017.12.002. 
553

554

555

556

557

558

559

560

561

562

563

564

565

566

567

568

569

570

571

572

573

(33) Cambier, P.; Pot, V.; Mercier, V.; Michaud, A.; Benoit, P.; Revallier, A.; Houot, S. Impact of Long-Term Organic Residue Recycling in Agriculture on Soil Solution Composition and Trace Metal Leaching in Soils. Sci. Total Environ. 2014, 499, 560-573. https://doi.org/10.1016/j.scitotenv.2014.06.105.

(34) Erickson, H. P. Size and Shape of Protein Molecules at the Nanometer Level Determined by Sedimentation, Gel Filtration, and Electron Microscopy. Biol. Proced. Online 2009, 11 (1), 32-51. https://doi.org/10.1007/s12575-009-9008-x.

(35) Noirot-Cosson, P. E.; Vaudour, E.; Gilliot, J. M.; Gabrielle, B.; Houot, S. Modelling the Long-Term Effect of Urban Waste Compost Applications on Carbon and Nitrogen Dynamics in Temperate Cropland. Soil Biol. Biochem. 2016, 94, 138-153. https://doi.org/10.1016/j.soilbio.2015.11.014.

(36) Vanden Nest, T.; Ruysschaert, G.; Vandecasteele, B.; Houot, S.; Baken, S.; Smolders, E.; Cougnon, M.; Reheul, D.; Merckx, R. The Long Term Use of Farmyard Manure and Compost: Effects on P Availability, Orthophosphate Sorption Strength and P Leaching. Agric. Ecosyst. Environ. 2016, 216, 23-33. https://doi.org/10.1016/j.agee.2015.09.009.

(37) Chalhoub, M.; Garnier, P.; Coquet, Y.; Mary, B.; Lafolie, F.; Houot, S. Increased Nitrogen Availability in Soil after Repeated Compost Applications: Use of the PASTIS Model to Separate Short and Long-Term Effects. Soil Biol. Biochem. 2013, 65, 144-157. https://doi.org/10.1016/j.soilbio.2013.05.023.

(38) Viollier, E.; Inglett, P. W.; Hunter, K.; Roychoudhury, A. N.; Van Cappellen, P. The Ferrozine Method Revisited: Fe (II)/Fe (III) Determination in Natural Waters. Appl. 
Geochemistry 2000, 15 (6), 785-790. https://doi.org/10.1016/S0883-2927(99)00097-9.

575 (39) Schwertmann, U. The Differentiation of Iron Oxides in Soils by Extraction with Ammonium Oxalate Solution. J. Plant Nutr. Soil Sci. 1964, 105, 194-202.

(40) Demaria, P.; Flisch, R.; Frossard, E.; Sinaj, S. Exchangeability of Phosphate Extracted by Four Chemical Methods. J. Plant Nutr. Soil Sci. 2005. https://doi.org/10.1002/jpln.200421463.

(41) Gu, S. Release of Dissolved and Colloidal Phosphorus from Riparian Wetlands: A Field and Laboratory Assessment of the Mechanisms and Controlling Factors, Université de Rennes, 2017.

(42) Lofts, S.; Tipping, E.; Hamilton-Taylor, J. The Chemical Speciation of Fe(III) in Freshwaters. Aquat. Geochemistry 2008, 14 (4), 337-358. https://doi.org/10.1007/s10498008-9040-5.

(43) Parc, S.; Nahon, D.; Tardy, Y.; Vieillard, P. Estimated Solubility Products and Fields of Stability for Cryptomelane, Nsutite, Birnessite, and Lithiophorite Based on Natural Lateritic Weathering Sequences. Am. Mineral. 1989, 74 (3-4), 466-475.

(44) Chalhoub, M.; Coquet, Y.; Vachier, P. Water and Bromide Dynamics in a Soil Amended with Different Urban Composts. Vadose Zo. J. 2013, 12 (1), 0. https://doi.org/10.2136/vzj2012.0056. 
